\title{
The Professional Development Activities of Academic Librarians: Does Institutional Support Make a Difference?
}

\section{W. Michael Havener and Wilbur A. Stolt}

\begin{abstract}
Academic libraries provide institutional support for professional development activities in the belief that such support fosters the continuing professional growth of their staff members. A 1991 survey of 185 academic librarians furnished data on the relationships between institutional provision of release time and financial assistance and librarians' participation in various types of professional development activities. Institutional support was found to be strongly correlated with librarians' activity levels.
\end{abstract}

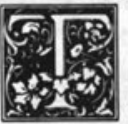

he library profession has long supported the idea of continuing professional development for its members. This support is reflected in the stated goals of our professional organizations. The Association of College and Research Libraries, for example, gives as its first major goal: "To contribute to the total professional development of academic and research librarians." 1

Despite widespread support for the concept of professional development, there is a lack of consensus on the purpose of such developmental activities. Julia Gelfand has narrowly defined professional development as "activity to enhance one's ability to perform work-related functions." 2 Sylvia Webb defines the term more broadly to include "a range of activi- ties aimed at developing and enhancing knowledge, skills and attitudes, and as such not only prepares the individual to carry out his or her job in the most effective manner, but also heightens motivation, and contributes to the individual's longer term progress and achievement." ${ }^{\prime 3}$ Such de-velopment is not narrowly aimed at the individual's current responsibilities, but rather should enhance performance "throughout the practitioner's working life."

Gelfand lists many different activities that fall under the umbrella of professional development, including "availing oneself of professional literature, attending relevant related workshops and seminars at local, regional, national, or international meetings, participating in continuing education courses and programs, and enrolling in academic courses." 5

W. Michael Havener and Wilbur A. Stolt are Co-directors of the University of Oklahoma Library and Information Research Center. Havener is also an Assistant Professor at the University of Oklahoma School of Library and Information Studies. Stolt is Director of Public Services at the University of Oklahoma Libraries. The authors wish to thank the Council on Library Resources. A1990/91 grant from CLR to the authors and Robert Swisher helped finance the research reported in this article. Philip Worrell, Graduate Research Assistant at the Library and Information Research Center, provided valuable assistance in the statistical analysis of data. 
Gelfand asserts, "Making these kinds of [professional development] opportunities available for employees to select is a responsibility of an organization and encouraging appropriate staff to participate in such activities becomes the role of its management." ${ }^{16}$ Others have suggested that support for professional development activities is "a shared responsibility between an individual engaging in appropriate activities, and the university providing appropriate time and resources." 7 Susan A. Stussy argues that the responsibility for professional development is shared not only by the individual and the employing institution but also by "the library profession as a whole" as represented by our professional organizations. ${ }^{8}$ A number of articles have focused specifically on the role of library associations in supporting professional development. ${ }^{9}$

This shared responsibility is apparently a reality for most academic librarians. Over half of those responding to a 1986 ACRL professional development survey indicated that their professional development activities were funded through "a combination of personal and institutional resources." 10

This paper examines the following questions:

- To what extent do academic institutions provide formal support for the continuing professional development of their librarians?

- Does the provision of this support have any effect upon the professional development activities of academic librarians?

Articles relevant to the first question will be discussed throughout this paper as specific types of institutional support are examined. There is little in the literature that attempts to answer the second question: Does the provision of institutional support have any effect upon professional development activities? Most articles on institutional support for professional development seem to be written with an underlying assumption that support does, indeed, have a positive influence upon professional development, but this positive correlation between sup- port and level of professional development activity has not been demonstrated in the literature. Ann Hare has found that there is a strong correlation between the importance academic library directors place upon professional development and the funding they provide for professional development activities. Hare also found that 88 percent of the directors in her study believed that providing release time encouraged such professional development activities. ${ }^{11}$ Stone has been advocating a structured approach to institutional support since the early 1970 s, and Grace Saw has gone as far as to state that effective professional development cannot proceed without the provision of institutional financial support and leaves of absence. ${ }^{12,13}$ However, the validity of the belief that institutional provision of release time and financial support correlate positively with professional development activities has not been concretely demonstrated.

\section{THE SURVEY}

New data from a 1991 survey of all academic librarians in Oklahoma can shed light upon both questions. Questionnaires were mailed to 230 academic librarians and, after one follow-up mailing, usable responses were received from 185 academic librarians, a response rate of 80.4 percent.

The primary focus of the study was upon academic librarians' career patterns rather than upon institutional support for professional development activities. However, information collected by the survey instrument included data on the availability of release time and financial assistance for four different types of professional development activities: professional meetings, continuing education programs, course work, and research.

First, this paper will provide a summary of the types of institutional support available to Oklahoma academic librarians, and then it will explore the relationships between institutional support and librarians' levels of participation in various types of formal and informal professional development activities. It will also explore their contributions to the profession through such 
activities as grant writing and administration, service in professional organizations, and contributions to the professional literature of library and information science.

The authors recognize that there are many other potential types of institutional support in addition to the two kinds (release time and financial support) examined in our study. Some of the additional means of support described in the literature include in-house training, secretarial support, computer/statistical support, student help, positive performance appraisals, and mentoring programs. ${ }^{14}$ However, time and money are the most commonly mentioned means of institutional support.

\section{INSTITUTIONAL SUPPORT}

The overwhelming majority of respondents ( 84.3 percent) reported that some type of institutional support for professional development activities was available to them. As table 1 indicates, when institutional support was available, it almost universally included release time. Only one librarian (.5 percent) reported institutional support that did not include release time. Over 65 percent of the respondents reported that their institutions provided both release time and financial assistance.

Formal institutional support for professional development activities varied dramatically from activity to activity. Approximately 80 percent of the librarians indicated that their institutions provided support for attendance at professional meetings while nearly half (48.6 percent) reported that support was available for attending continuing education programs. Fewer than 30 percent had support for credit courses. The type of professional development activity receiving the least support was research. Fewer than 15 percent of the respondents reported any support for research activities. The availability of support for each of these activities is shown in table 2.

This overall summary of institutional support can be broken down for further analysis. Just as overall support varied by activity, availability of the two types of support examined varied, depending on the type of professional development activity. For all activities, release time was provided more often than financial aid. For three of the professional development activities monitored (meeting attendance, continuing education, and credit courses), it was unusual for financial support to be provided without release time also being available. Table 3 , which illustrates release time, shows figures only slightly below table 2 for most activities. Nearly 80 percent of the librarians indicated that their institutions provided release time for professional meetings, but only 10 percent worked in institutions that provided release time for research. Release time for continuing education programs and credit course work fell between these two extremes.

For each of the four types of professional development shown in table 3,

TABLE 1

PROVISION OF INSTITUTIONAL SUPPORT FOR

PROFESSIONAL DEVELOPMENT ACTIVITIES $(n=185)$

\begin{tabular}{lcc}
\hline Type of Support & $\begin{array}{c}\text { No. of } \\
\text { Subjects }\end{array}$ & $\%$ \\
\hline No support & 29 & 15.7 \\
Release time & 155 & 83.8 \\
Financial assistance & 122 & 65.9 \\
Both time and financial & 121 & 65.4 \\
\hline
\end{tabular}

Percentages add up to more than $100 \%$ because most subjects fall into more than one of the categories in this table.

TABLE 2

INSTITUTIONAL SUPPORT BY PROFESSIONAL DEVELOPMENT ACTIVITY $(n=185)$

\begin{tabular}{lcc}
\hline Activity & $\begin{array}{c}\text { No. of } \\
\text { Subjects }\end{array}$ & $\%$ \\
\hline Meetings & 147 & 79.5 \\
Continuing education & 90 & 48.6 \\
Credit courses & 52 & 28.1 \\
Research & 26 & 14.1 \\
\hline
\end{tabular}

Percentages add up to more than $100 \%$ because many subjects fall into more than one of the categories in this table. 
TABLE 3

INSTITUTIONAL PROVISION OF RELEASE TIME $(n=185)$

\begin{tabular}{lcc}
\hline Activity & $\begin{array}{c}\text { No. of } \\
\text { Subjects }\end{array}$ & $\%$ \\
\hline Meetings & 146 & 79.0 \\
Continuing education & 90 & 48.6 \\
Credit courses & 49 & 26.5 \\
Research & 19 & 10.2 \\
\hline
\end{tabular}

TABLE 4

INSTITUTIONAL PROVISION OF FINANCIAL SUPPORT FOR PROFESSIONAL DEVELOPMENT ACTIVITIES $(n=185)$

\begin{tabular}{lcr}
\hline Activity & $\begin{array}{c}\text { No. of } \\
\text { Subjects }\end{array}$ & \multicolumn{1}{c}{$\%$} \\
\hline Meetings & 116 & 62.7 \\
Continuing education & 65 & 35.1 \\
Credit courses & 35 & 18.9 \\
Research & 13 & 7.0 \\
\hline
\end{tabular}

more institutions provided release time than financial assistance. However, the relative support provided for each activity remained the same. More financial support was available for attending meetings than for any of the other three professional development activities. The next greatest level of support was for continuing education programs, followed by credit courses. Institutions were least likely to finance research activities. The number and percentage of librarians in institutions providing financial as- sistance for each activity are shown in table 4.

If the support patterns for each of these four types of professional development activities are examined individually, similar patterns emerge. Table 5 shows the types of support available for professional meetings, continuing education programs, credit courses, and research.

Although provision of institutional support varied significantly across types of professional development activity, patterns of support tended to be similar. For all types of professional development activity, release time was more prevalent than financial assistance. However, if any institutional support was available, the most common pattern was to offer both release time and financial assistance. The only exception to this pattern was for research support. Institutional support for research was much less common than for the other types of professional development activity examined, but when it was offered it was generally either release time only or financial support only. Only 23 percent of those at institutions providing research support reported that both time and money were available.

\section{RELATIONSHIPS BETWEEN INSTITUTIONAL SUPPORT AND SUBJECTS' PROFESSIONAL ACTIVITIES}

Institutions provide various incentives, such as release time and financial support, in an effort to encourage and reward activities that they want their librarians to pursue. To assess whether

TABLE 5

INSTITUTIONAL SUPPORT FOR PROFESSIONAL DEVELOPMENT ACTIVITIES $(n=185)$

\begin{tabular}{lrrrrrrrr}
\hline & \multicolumn{3}{c}{ Meetings } & \multicolumn{2}{c}{$\begin{array}{c}\text { Eontinuing } \\
\text { Education }\end{array}$} & \multicolumn{2}{c}{ Credit Courses } & \multicolumn{2}{c}{ Research } \\
\cline { 2 - 9 } & \multicolumn{1}{c}{ No. } & \multicolumn{1}{c}{$\%$} & \multicolumn{1}{c}{ No. } & \multicolumn{1}{c}{$\%$} & No. & \multicolumn{1}{c}{$\%$} & No. & $\%$ \\
\hline No support & 38 & 20.5 & 95 & 51.4 & 133 & 71.9 & 159 & 85.9 \\
Time only & 31 & 16.8 & 25 & 13.5 & 17 & 9.2 & 13 & 7.0 \\
Financial only & 1 & 0.5 & 0 & 0.0 & 3 & 1.6 & 7 & 3.8 \\
Both & 115 & 62.2 & 65 & 35.1 & 32 & 17.3 & 6 & 3.2 \\
\hline
\end{tabular}


such rewards are associated with any variations in librarians' professional activities, data were analyzed to see if any statistically significant relationships existed between the institutional support variables and the extent to which librarians participated in both formal and informal continuing professional development activities and/or the types of contributions they made to the profession.

Formal activities included membership in professional library associations, attendance at professional meetings, workshop participation, enrollment in credit courses, and pursuit of additional degrees. Informal activities included visits to other libraries and reading professional books and journals.

The professional development activities listed above are not ends in themselves, but rather the means to encourage librarians to make greater contributions to their home institutions and to the profession as a whole. The data collected in this survey cannot illustrate whether the qualitative performance of librarians was improved through participation in professional development activities, but it can provide quantitative data showing the relationships between support and certain types of contributions to the profession. Those contributions include grant activity, papers presented, association committee service, and publication activity.

Because of the high degree of overlap between release time and financial support, all statistical analyses were based upon availability or nonavailability of either type of institutional support for a given activity. The analyses did not differentiate between time and financial support. Relationships between these variables and meeting support were analyzed for statistical significance at the .05 level. ${ }^{15}$

\section{Support for Professional Meetings}

The environment in which academic librarians work is constantly changing because of technological advances, the information explosion, and financial reintrenchment. Interaction with colleagues at other institutions can give academic librarians new insights on how best to serve their users in a changing environment. Institutional support for attending professional meetings is designed to encourage such professional interactions. Professional meeting support fosters meeting attendance and may also encourage other related activities such as joining library associations, serving on committees, and presenting papers.

The importance institutions place upon association participation is reflected in Donna Pittman Blomberg and Karen Chapman's finding that over 90 percent of Association of Research Libraries members use involvement in professional organizations as a factor in staff evaluations, and that 93 percent of those libraries support attendance at national library association meetings by providing travel funds. ${ }^{16}$

Analysis of survey responses indicates that institutional support for professional meetings does, indeed, meet its objectives. As table 6 shows, during 1990 attendance rates for librarians who

\section{TABLE 6}

ACADEMIC LIBRARIANS WHO ATTENDED

AT LEAST ONE MEETING DURING $1990(n=185)$

\begin{tabular}{lcccc}
\hline & \multicolumn{2}{c}{ With Meeting Support } & \multicolumn{2}{c}{ Without Meeting Support } \\
& \multicolumn{2}{c}{$(n=147)$} & & \multicolumn{2}{c}{\begin{tabular}{c}
$(n 8)$ \\
\cline { 2 - 5 }
\end{tabular}} & No. & $\%$ & No. & $\%$ \\
\hline Library association meetings & 128 & 87.1 & 22 & 57.9 \\
Workshops & 137 & 93.2 & 24 & 63.2 \\
\hline
\end{tabular}

For library association meetings: $x^{2}=14.912 ; d f=1 ; p=.0001$.

For workshops: $x^{2}=21.546 ; d f=1 ; p=.0000$. 
indicated availability of institutional support for professional meetings were 30 percent higher at both professional meetings and workshops when compared to the rates for their nonsupported colleagues.

The mean number of library association meetings and continuing education workshops attended by librarians with and without meeting support was also analyzed. As table 7 shows, the mean number of library association meetings attended by librarians at institutions providing meeting support was nearly twice the number for librarians whose institutions did not provide such support, and the differences in workshop attendance were even greater.

TABLE 7

MEAN NUMBER OF MEETINGS ATTENDED $(n=185)$

\begin{tabular}{lcc}
\hline & $\begin{array}{c}\text { With } \\
\text { Meeting } \\
\text { Support } \\
(n=147)\end{array}$ & $\begin{array}{c}\text { Without } \\
\text { Meeting } \\
\text { Support } \\
(n=38)\end{array}$ \\
\hline $\begin{array}{c}\text { Library association } \\
\text { meetings }\end{array}$ & 3.48 & 1.76 \\
Workshops & 3.27 & 1.29 \\
\hline
\end{tabular}

For library association meetings: $F$ value $=$ 4.78; $p=.000$.

For workshops: $F$ value $=3.54 ; p=.000$.

The data demonstrated a positive correlation between institutional support for meetings and actual meeting attendance. Did such support also have a positive correlation with the other types of association activities mentioned earlier, such as association membership, committee service, and presentation of papers? Such correlations seemed likely. Meeting attendance is a gauge of association involvement. Indeed, membership in an association is often a prerequisite for institutional support for meetings. Similarly, it is difficult to serve on association committees if one cannot attend meetings on a regular basis, and delivering a paper without being present is impossible.

When data were analyzed, librarians with institutional meeting support had statistically higher rates of library association membership and committee service.
The majority of those eligible for meeting support (51.7 percent) served on at least one library association committee, a service rate almost twice as high as that of their nonsupported colleagues.

Very few librarians in the population had presented papers at meetings during the last year. The eleven subjects (6.0 percent) who presented papers represented too small a group to detect any statistically significant differences in the meeting support status of these presenters.

Statistics for all three types of activity are given in table 8 .

\begin{tabular}{|c|c|c|c|c|}
\hline & \multicolumn{2}{|c|}{$\begin{array}{c}\text { With } \\
\text { Meeting } \\
\text { Support } \\
(n=147)\end{array}$} & \multicolumn{2}{|c|}{$\begin{array}{l}\text { Without } \\
\text { Meeting } \\
\text { Support } \\
(n=38)\end{array}$} \\
\hline & No. & $\%$ & No. & $\%$ \\
\hline $\begin{array}{l}\text { Library } \\
\text { association } \\
\text { membership }\end{array}$ & 135 & 91.8 & 30 & 78.9 \\
\hline $\begin{array}{l}\text { Library } \\
\text { association } \\
\text { committee }\end{array}$ & 76 & 51.7 & 10 & 26.3 \\
\hline Presented paper & 8 & 5.4 & 3 & 7.9 \\
\hline
\end{tabular}

For library association memberships:

$x^{2}=3.952 ; d f=1 ; p=.0468$.

For library association committee: $x^{2}=6.834$; $d f=1 ; p=.0089$.

Numbers are too small for a meaningful statistical analysis of presented papers.

The mean number of association memberships held by librarians with and without meeting support was also analyzed, and a $t$-test was performed to test for statistical significance. The results are shown in table 9.

Thus, although the average number of library association memberships held by

TABLE 9

MEAN NUMBER OF LIBRARY ASSOCIATION MEMBERSHIPS $(n=185)$

\begin{tabular}{cc}
\hline $\begin{array}{c}\text { With Meeting Support } \\
(n=147)\end{array}$ & $\begin{array}{c}\text { Without Meeting } \\
\text { Support }(n=38)\end{array}$ \\
\hline 2.24 & 1.66 \\
\hline
\end{tabular}

$F$ value $=1.37 ; p=.199$. 
librarians reporting support was 0.58 greater than for those with no support, the difference is not statistically significant at the 0.05 level.

\section{Support for Continuing Education}

As James M. Matarazzo has noted, librarians need "to continuously update their skills, methods, and approaches to meet the challenges and changes in technology, in industry, and in the scope of their responsibilities."17 Continuing education programs are an important way of keeping librarians' skills and knowledge current.

The authors' study found that institutional support for attendance at continuing education programs was strongly related to librarians' actual attendance at such workshops. Even without institutional support, a substantial percentage of librarians ( 77.9 percent) attended at least one workshop during the year. However, when institutional support was provided, the percentage attending increased to 96.7 percent. The probability of this difference occurring by chance is .0003 .

As table 10 shows, provision of continuing education support almost doubled the mean number of workshops attended, and the differences shown are statistically significant.

TABLE 10

WORKSHOP ATTENDANCE

$$
(n=185)
$$

\begin{tabular}{cc}
\hline $\begin{array}{c}\text { With Continuing } \\
\text { Education Support } \\
(n=90)\end{array}$ & $\begin{array}{c}\text { Without Continuing } \\
\text { Education Support } \\
(n=95)\end{array}$ \\
\hline 3.72 & 2.04 \\
\hline
\end{tabular}

$F$ value $=1.55 ; p=.036$.

An important aspect of continuing education is self-education through regular reading of current professional literature. Matarazzo has expressed the belief that "keeping current with the literature is a prerequisite of any continuing education program." ${ }^{18}$ Reading professional journals is a vital part of this process, but as Peter Hernon has pointed out, monographs also form an important part of our professional literature. ${ }^{19}$

The relationships between institutional support for continuing education programs and four types of self-directed continuing education activities were examined in our study. Three of these activities involved reading: number of library journals read regularly, number of other professional journals read regularly for purposes other than book selection, and number of professional books read. The fourth activity analyzed was traveling to observe other library-related practices, techniques, or facilities.

Librarians with institutional support for continuing education activities read more library journals and made more visits to other libraries than those without such support. However, those differences were not statistically significant at the 0.05 level. The relationship between institutional support for continuing education and the reading of professional books and nonlibrary professional journals was the opposite of what was expected. Librarians without continuing education support read more professional books and more nonlibrary journals. Table 11 shows statistics for all four of these variables.

TABLE 11

MEAN NUMBER OF ITEMS

READ AND VISITS MADE

DURING $1990(n=185)$

\begin{tabular}{lcc}
\hline & $\begin{array}{c}\text { With } \\
\text { Continuing } \\
\text { Education } \\
\text { Support } \\
(n=90)\end{array}$ & $\begin{array}{c}\text { Without } \\
\text { Continuing } \\
\text { Education } \\
\text { Support } \\
(n=95)\end{array}$ \\
\hline $\begin{array}{l}\text { Library journals } \\
\begin{array}{l}\text { Other professional } \\
\text { journals }\end{array}\end{array}$ & 4.64 & 3.32 \\
$\begin{array}{l}\text { Professional books } \\
\text { Visits to other }\end{array}$ & 0.61 & 1.09 \\
institutions & 3.90 & 4.14 \\
\hline
\end{tabular}

For library journals read: $F$ value $=1.48$; $p=.060$.

For other professional journals read:

$F$ value $=5.47 ; p=.000$

For professional books read: $F$ value $=2.92$; $p=.000$.

For visits: $\mathrm{F}$ value $=1.46 ; \mathrm{p}=.072$. 


\section{Support for Credit Courses}

The educational levels of librarians at institutions that provided support for credit courses were essentially the same as the levels of librarians at institutions which did not provide such support (39.2 percent with degrees beyond the first master's versus 37.7 percent). However, these two groups varied dramatically in their current participation in credit courses as well as in their pursuit of additional degrees.

Academic librarians at institutions providing support for credit courses enrolled in credit courses at rates over four times higher than those not receiving

TABLE 12

PERCENTAGE OF LIBRARIANS

DOING CREDIT COURSE WORK DURING $1990(n=185)$

\begin{tabular}{lcccc}
\hline & \multicolumn{2}{c}{$\begin{array}{l}\text { With Course } \\
\text { Support } \\
(n=52)\end{array}$} & \multicolumn{2}{c}{$\begin{array}{c}\text { Without } \\
\text { Course } \\
\text { Support } \\
(n=133)\end{array}$} \\
\cline { 2 - 5 } & No. & $\%$ & No. & $\%$ \\
\hline $\begin{array}{c}\text { Enrolled in credit } \\
\text { course }\end{array}$ & 28 & 53.8 & 16 & 12.0 \\
$\begin{array}{c}\text { Enrolled in } \\
\text { degree program }\end{array}$ & 19 & 36.5 & 8 & 6.0 \\
\hline
\end{tabular}

For credit courses: $x^{2}=33.791 ; d f=1$;

$p=.0000$.

For degree programs: $x^{2}=25.548 ; d f=1$; $p=.0000$.

TABLE 13

MEAN NUMBER OF PROFESSIONAL ITEMS READ DURING $1990(n=185)$

\begin{tabular}{lcc}
\hline & $\begin{array}{c}\text { With Course } \\
\text { Support } \\
(n=52)\end{array}$ & $\begin{array}{c}\text { Without } \\
\text { Course } \\
\text { Support } \\
(n=133)\end{array}$ \\
\hline $\begin{array}{c}\text { Library journals } \\
\text { read }\end{array}$ & 4.63 & 3.70 \\
$\begin{array}{c}\text { Other professional } \\
\text { journals read }\end{array}$ & 0.98 & 0.81 \\
$\begin{array}{c}\text { Professional books } \\
\text { read . }\end{array}$ & 6.52 & 3.05 \\
\hline
\end{tabular}

For library journals: $F$ value $=1.86 ; p=.005$.

For other professional journals: $F$ value $=2.01$; $p=.002$.

For professional books: $F$ value $=7.77$; $p=.000$. such institutional support. Librarians receiving support for credit courses were also over six times as likely to have an additional degree in progress. As table 12 reflects, those differences were statistically significant.

The survey data also show that those receiving institutional support for enrollment in credit courses read more library journals, more nonlibrary professional journals, and more books. Figures for these activities are given in table 13.

\section{Support for Research}

The participation of academic librarians in research and publication provides benefits for individual librarians and the libraries in which they work. Dale S. Montanelli and Patricia F. Stenstrom cite job advancement and personal recognition as potential advantages to the individual. They also state that research benefits the institution by generating knowledge which can improve library services, encouraging innovation, increasing the library's responsiveness to change, and improving relationships with teaching faculty. ${ }^{20}$

Many libraries attempt to foster research through various support mechanisms, such as those described by Bonnie Gratch: scheduling time for research, budgeting funds for research support, promoting collegial contacts, and providing educational and operational support. ${ }^{21}$ However, even when institutions recognize the benefits of research, and therefore encourage or require librarians to engage in research, institutional structures to support research activities are often not provided. Emmick reports, "Libraries that provide release time for research-related activities . . . are in the minority." ${ }^{22}$ Her contention is supported by at least two other studies. In their survey of Virginia academic libraries, Donald J. Kenney and Gail McMillan found that 31.9 percent provided leave and 20 percent gave financial support for research activities. ${ }^{23}$ Gray and McReynolds' study of academic libraries in six southeastern states found that only 19 percent provided paid leaves for research. ${ }^{24}$ 
In the authors' study, institutional support was lower for research than for the other three types of professional development activities examined. Only 26 subjects ( 14.1 percent) reported that research support was available from their institutions. Although institutional research was available to relatively few librarians, two major indicators of research activity, grants and publications, indicate that the research productivity of those few supported individuals was dramatically higher than that of their nonsupported counterparts.

Subjects receiving institutional support were twice as likely to have received grants during 1990 . Nearly 27 percent of those receiving research support reported grant activity during the year while only 13.2 percent of those not receiving support reported such activity.

Analogous differences between these two groups (those with research support and those without support) were evident when career and annual (1990) publication patterns were analyzed. Librarians at institutions that provided research support had significantly higher publication rates. Statistics were compiled for six different types of publications: book reviews, articles other than book reviews, books, book chapters, proceedings, and journal editorships. Analyses were performed to provide statistics on individual publication types and to produce composite figures summarizing all publication activity.

Table 14 illustrates that over 60 percent of the librarians with institutional research support had published during their careers. This figure drops to under 36 percent for those without such support. Since these composite publication figures include book reviews, which are not generally considered to be research publications, differences between publication activity were also computed without that variable. The differences between groups remained statistically significant at the .05 level.

All publications during the course of a librarian's career may not have been finished in the same type of support environment. Support patterns within an
TABLE 14

LIBRARIANS WHO HAVE

PUBLISHED DURING THEIR

CAREERS $(n=185)$

\begin{tabular}{lcccc}
\hline & $\begin{array}{c}\text { With } \\
\text { Research } \\
\text { Support } \\
(n=26)\end{array}$ & \multicolumn{2}{c}{$\begin{array}{c}\text { Without } \\
\text { Research }\end{array}$} \\
\cline { 2 - 5 }$(n=159)$ \\
\hline No. & $\%$ & No. & $\%$ \\
\hline $\begin{array}{c}\text { Any type of } \\
\text { publication }\end{array}$ & 16 & 61.5 & 57 & 35.8 \\
$\begin{array}{c}\text { Any type of } \\
\text { publication except } \\
\text { book review }\end{array}$ & 14 & 53.8 & 48 & 30.2 \\
\hline
\end{tabular}

For any type: $x^{2}=5.145 ; d f=1 ; p=.0233$.

For any except book reviews: $x^{2}=4.601$; $d f=1 ; p=.0319$.

institution often change over time, and librarians (like the majority of those in the authors' study) who have worked at more than one institution are even more likely to have experienced varying levels of institutional support. Because of this, publications during the last full year reported (1990) are probably a more accurate reflection of the relationship between institutional support and publication activity than are career publications. When 1990 publications were analyzed, with and without book reviews, the annual differences between the two groups were even greater than the career differences. (See table 15.)

When publication activity is analyzed by type of publication, the career pub-

TABLE 15

SUBJECTS WHO PUBLISHED DURING $1990(n=185)$

\begin{tabular}{lcccc}
\hline \hline & $\begin{array}{c}\text { With } \\
\text { Research } \\
\text { Support } \\
(n=26)\end{array}$ & $\begin{array}{c}\text { Without } \\
\text { Research }\end{array}$ & $\begin{array}{c}\text { Support } \\
(n=159)\end{array}$ \\
\cline { 2 - 5 } & No. & $\%$ & No. & $\%$ \\
\hline $\begin{array}{c}\text { Any type of } \\
\text { publication }\end{array}$ & 14 & 53.8 & 31 & 19.5 \\
$\begin{array}{c}\text { Any type of } \\
\text { publication except } \\
\text { book review }\end{array}$ & 10 & 38.5 & 26 & 16.4 \\
\hline
\end{tabular}

For any type: $x^{2}=12.518 ; d f=1 ; p=.0004$.

For any except book reviews: $x^{2}=5.630 ; d f=1$; $p=.0177$. 
TABLE 16

INSTITUTIONAL RESEARCH SUPPORT AND CAREER

PUBLICATION ACTIVITY $(n=185)$

\begin{tabular}{lrrrr}
\hline & \multicolumn{2}{c}{$\begin{array}{c}\text { With } \\
\text { Research } \\
\text { Support } \\
(n=26)\end{array}$} & \multicolumn{2}{c}{$\begin{array}{c}\text { Without } \\
\text { Research } \\
\text { Support } \\
(n=159)\end{array}$} \\
\cline { 2 - 5 } & No. & \multicolumn{1}{c}{$\%$} & No. & \multicolumn{1}{c}{$\%$} \\
\hline Articles & 12 & 46.2 & 38 & 23.2 \\
Book reviews & 8 & 30.8 & 28 & 17.6 \\
Books & 5 & 19.2 & 11 & 6.9 \\
Book chapters & 4 & 15.4 & 15 & 9.4 \\
Proceedings & 1 & 3.8 & 20 & 12.6 \\
Journal editorships & 1 & 3.8 & 8 & 5.0 \\
\hline
\end{tabular}

For articles: $x^{2}=4.540 ; d f=1 ; p=.0331$.

For book reviews: $x^{2}=1.701 ; d f=1$; $p=.1922$.

For books: $x^{2}=.0902 ; d f=1 ; p=.0902$.

Numbers are too small for meaningful statistical analyses of book chapters, proceedings, and journal editorships.

lication activity of those with institutional support was higher for four of the six types of publishing activity examined. However, as table 16 shows, only the difference for journal articles is statistically significant. Subjects receiving institutional research support were twice as likely to publish journal articles as those lacking such support. Although the figures are not statistically signifi-

TABLE 17

INSTITUTIONAL RESEARCH SUPPORT AND 1990 PUBLICATION $\operatorname{ACTIVITY}(n=185)$

\begin{tabular}{lcrrr}
\hline & \multicolumn{2}{c}{$\begin{array}{c}\text { With } \\
\text { Research } \\
\text { Support } \\
(n=26)\end{array}$} & \multicolumn{2}{c}{$\begin{array}{c}\text { Without } \\
\text { Research } \\
\text { Support } \\
(n=159)\end{array}$} \\
\cline { 2 - 5 } & No. & \multicolumn{1}{c}{$\%$} & No. & $\%$ \\
\hline Articles & 8 & 30.8 & 11 & 6.9 \\
Book reviews & 6 & 23.1 & 10 & 6.3 \\
Books & 1 & 3.8 & 7 & 4.4 \\
Book chapters & 2 & 7.7 & 1 & 0.6 \\
Proceedings & 0 & 0.0 & 7 & 4.4 \\
Journal editorships & 1 & 3.8 & 6 & 3.8 \\
\hline
\end{tabular}

For articles: $x^{2}=11.327 ; d f=1 ; p=.0008$.

For book reviews: $x^{2}=5.988 ; d f=1 ; p=.0144$.

Numbers are too small for meaningful statistical analyses of books, book chapters, proceedings, and journal editorships. cant, those receiving institutional support also published an observably higher percentage of books, book chapters, and book reviews.

The analysis of publication rates for proceedings produced unexpected results. Unlike most other types of publications, which had a positive correlation with research support, those without research support published papers in proceedings four times more often than those with support. This figure is not statistically significant because of the small number of subjects involved in this kind of publication, but it does underscore the fact that other elements besides institutional support influence publication patterns.

When publication activity for the most recent year (1990) was analyzed, only the two most common types of publications, articles and book reviews, were present in large enough numbers for meaningful statistical analyses. In both cases, publication productivity of those with research support was approximately four times that of those lacking such institutional support, as shown in table 17.

Positive correlations between institutional research support and grant and publication productivity are clearly demonstrated by this study. Institutional support apparently makes a difference in librarians' research output, but does it also influence other activities which can help to develop research interests, such as professional reading or visits to other libraries?

Four factors were examined for relationships between each factor and research support. Those factors were: reading of professional books, reading of professional journals in the field, reading of professional journals in other fields, and visits to other libraries. Librarians receiving institutional research support were more involved in three of these four activities (reading professional books, reading journals in other fields, and visiting libraries), but none of the differences was statistically significant. There were statistically significant differences in the fourth factor, reading of library journals, but not in the 
TABLE 18

MEAN NUMBER OF ITEMS

READ AND VISITS MADE

DURING $1990(n=185)$

\begin{tabular}{lcc}
\hline & $\begin{array}{c}\text { With } \\
\text { Research } \\
\text { Support } \\
(n=26)\end{array}$ & $\begin{array}{c}\text { Without } \\
\text { Research } \\
\text { Support } \\
(n=159)\end{array}$ \\
\hline $\begin{array}{l}\text { Library journals } \\
\text { Other professional } \\
\text { journals }\end{array}$ & 3.35 & 4.06 \\
$\begin{array}{l}\text { Professional books } \\
\text { Visits to other }\end{array}$ & 0.92 & 0.85 \\
institutions & 6.08 & 3.69 \\
\hline
\end{tabular}

For library journals read: $F$ value $=2.31$;

$p=.016$.

For other professional journals read: $F$ value $=$ $1.85 ; p=.072$.

For professional books read: $F$ value $=1.53$; $p=.213$.

For visits: $F$ value $=1.19 ; p=.511$.

direction expected. Librarians at institutions that did not provide research support read more library journals than did those at institutions that did provide such support. These data are shown in table 18.

\section{CONCLUSIONS}

The results of this study confirm Saw's belief that a supportive organizational climate has a major positive impact on librarians' professional development activities. ${ }^{25}$ Institutional support policies correlate positively with academic librarians' professional activities. The existence of positive correlations between institutional support and academic librarians' professional activities does not prove causality. Nevertheless, these correlations do strongly suggest that institutions wanting to encourage their librarians' continuing professional development can do so by providing release time and financial support for their staff members.

Further findings suggest that academic libraries can influence the types of professional development activities in which their employees engage by targeting the activities that they support with release time and financial assistance. Librarians who receive institutional support to attend meetings are more active in professional organizations. Librarians who receive institutional support for continuing education programs attend more workshops. Librarians who receive institutional support for credit courses enroll in more courses and degree programs. Librarians who receive institutional support for research publish more and receive more grants.

Some of these results may appear to be common sense, but the strength of many of the correlations examined indicates that institutional support can be a stronger factor than many might have imagined. Certainly, many academic librarians continue to pursue professional development activities even without such support, and individuals' internal motivations such as personal satisfaction play an important role in their level of professional growth. ${ }^{26}$ As noted earlier in this paper, the individual and the institution share responsibility for continuing professional development, but the results of this study indicate that institutional support policies can greatly facilitate librarians' professional development.

\section{REFERENCES AND NOTES}

1. ALA Handbook of Organization 1991/1992, (Chicago: ALA, 1991), 44.

2. Julia Gelfand, "Professional Development for Reference and Adult Services Librarians," RQ 24 (Summer 1985): 402.

3. Sylvia P. Webb, "Continuing Professional Development: The Way Forward," Information Management Report, (Apr. 1992): 14.

4. Ibid.

5. Gelfand, "Professional Development for Reference and Adult Services Librarians," 402.

6. Ibid.

7. Ilene F. Rockman, "Promoting Professional Development: A Local Approach," College \& Research Libraries News 50 (Nov. 1989): 903. 
8. Susan A. Stussy, "A Need for the Professional Development of Academic Librarians," Catholic Library World 59 (Sept./Oct. 1987): 82-83.

9. Donald J. Kenney and Gail McMillan, "State Library Associations: How Well Do They Support Professional Development?" RQ 31 (Spring 1992): 377-86; Kathy L. Warye, "SLA's Professional Development Program: Where It's Been and Where It's Going," Special Libraries 78 (Fall 1987): 251-56; Gelfand, "Professional Development for Reference and Adult Services Librarians" [a description of RASD's support of professional development activities], 402-3.

10. Sandy Donnelly, "Professional Development Survey," College \& Research Libraries News 48 (Apr. 1987): 200.

11. Ann Hare, "Professional Development in the 1980s in College Libraries in the Southeast," Southeastern Librarian 39 (Spring 1989): 18-19.

12. Elizabeth W. Stone, New Directions in Staff Development, (Chicago: ALA, Library Administration Division, 1971); Elizabeth W. Stone, Continuing Library Education as Viewed in Relation to Other Continuing Professional Education Movements, (Washington, D.C.: American Society for Information Science, 1974).

13. Grace Saw, "Staff Professional Development in Libraries: The Organisation's Role," Australasian College Libraries 7 (Mar. 1989): 22.

14. Saw, "Staff Professional Development in Libraries: The Organisation's Role," 17, 19-20; Melissa D. Trevvett, "The Professional Development Program," Journal of Academic Librarianship 17 (May 1991): 73-75; Peter Durey, "The Appraisal and Professional Development of Staff in Academic Libraries," New Zealand Libraries 46 (Mar. 1991): 7-9; Donald J. Kenney and Gail McMillan, "Librarians in Academic Limbo: Support for Scholarship," The Southeastern Librarian 39 (Winter 1989): 139-41.

15. All means were compared using t-tests. Nominal measurements were analyzed using chi-square tests, and all reported $p^{\prime}$ s for chi-square tests reflect Yates' correction. All analyses were done using SPSS PC+.

16. Donna Pittman Blomberg and Karen Chapman, "Survey of Travel Support Policies at ARL Libraries," Journal of Academic Librarianship 15 (May 1989): 90-93.

17. James M. Matarazzo, "Continuing Professional Education," Special Libraries 78 (Fall 1987): 247.

18. Ibid., 249.

19. Peter Hernon, "Academic Librarians and the Library and Information Science Monograph: An Exploratory Study," College \& Research Libraries 52 (Nov. 1991): 507-19.

20. Dale S. Montanelli and Patricia F. Stenstrom, "The Benefits of Research for Academic Librarians and the Institutions They Serve," College \& Research Libraries 47 (Sept. 1986): 482-85.

21. Bonnie Gratch, "Fostering Research Activity: Examples of Institutional Support," College \& Research Libraries News 50 (Dec. 1989): 979-80.

22. Nancy J. Emmick, "Release Time for Professional Development: How Much for Research?" in Academic Libraries: Myths and Realities, Chicago: ACRL, 1984.

23. Kenney and McMillan, "Librarians in Academic Limbo: Support for Scholarship," 140.

24. Becky Bolte Gray and Rosalee McReynolds, "A Comparison of Academic Librarians with and without Faculty Status in the Southeast," College \& Research Libraries 44 (July 1983): 285 . The figure of 19 percent was derived by combining categories from their Table 1.

25. Saw, "Staff Professional Development in Libraries: The Organisation's Role," 22.

26. Kenney and McMillan, "Librarians in Academic Limbo: Support for Scholarship," 141. 